ISSN 2077-8333 (print)

ISSN 2311-4088 (online)

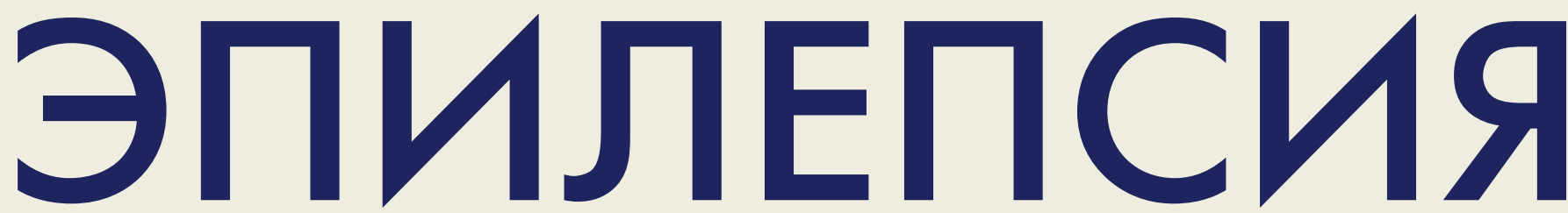

и пароксизмальные

Состояния

2021 Том 13 №3

EPILEPSY AND PAROXYSMAL CONDITIONS

2021 Vol. 13 №3 


\section{Reiterating the role of corpus callosum in generalization of interictal and ictal epileptiform discharges: a case report with post-callosotomy intracranial electroencephalography in Lennox-Gastaut syndrome}

Gopinath S. , Pillai A. ${ }^{1}$, Diwan A. ${ }^{2}$, Pattisapu J.V. ${ }^{3,4}$, Radhakrishnan K. ${ }^{1}$

${ }^{1}$ Amrita Advanced Centre for Epilepsy, Amrita Institute of Medical Science (Ponekkara, P.0, Kochi, Kerala 682041, India)

${ }^{2}$ Narayani Hospital (Mumbai Naka, Shri Vallabh Nagar, Nashik, Maharashtra 422006, India)

${ }^{3}$ University of Central Florida College of Medicine (6850 Lake Nona Blvd., Orlando, FI 32827, USA)

${ }^{4}$ Arnold Palmer Hospital for Children (92 W Miller Str., Orlando, FL 32806, USA)

Corresponding author: Siby Gopinath, e-mail: sibygopinath@aims.amrita.edu

\footnotetext{
SUMMARY

Lennox-Gastaut syndrome (LGS) is an epileptic encephalopathy characterized by delayed mental development and intractable multiple seizure types, predominantly tonic. Drop attacks are the commonest and the most disabling type of seizures. Resective surgery is often not possible in LGS as the electroencephalogram (EEG) abnormalities are usually multifocal and generalized, and magnetic resonance image is often either normal or multilesional. We report a case of LGS with bilateral parieto-occipital gliosis where EEG before and after callosotomy demonstrated synchronized bilateral interictal epileptiform discharges and ictal discharges becoming desynchronized and running down. This phenomenon emphasizes the role of the corpus callosum in secondary bilateral synchrony.

KEYWORDS

Epileptic encephalopathy, Lennox-Gastaut syndrome, corpus callosum, callosotomy.

Received: 08.06.2021; in the revised form: 07.07.2021; accepted: 12.08.2021

Conflict of interests

The authors declare no conflict of interest regarding this publication.

Authors' contribution

All authors contributed equally to this article.

For citation

Gopinath S., Pillai A., Diwan A., Pattisapu J.V., Radhakrishnan K. Reiterating the role of corpus callosum in generalization of interictal and ictal epileptiform discharges: a case report with post-callosotomy intracranial electroencephalography in LennoxGastaut syndrome. Epilepsia i paroksizmal'nye sostoania / Epilepsy and Paroxysmal Conditions. 2021; 13 (3): 249-253. https:// doi.org/10.17749/2077-8333/epi.par.con.2021.086
} 
Подтверждение роли мозолистого тела в генерализации интериктальных и иктальных эпилептиформных разрядов: клинический случай с выполнением интракраниальной электроэнцефалографии после каллозотомии при синдроме Леннокса-Гасто

Гопинатх C. ${ }^{1}$, Пиллаи А. ${ }^{1}$, Диван A. ${ }^{2}$, Паттисапу Дж.В. ${ }^{3,4}$, Радхакришнан K. ${ }^{1}$

${ }^{1}$ Передовой центр эпилепсии «Амрита», Институт медицинских наук «Амрита» (Понеккара, П.О., Кочи, Керала 682041, Индия)

2 Больница «Нараяни» (Мумбаи Нака, Шри Валлабх Нагар, Нашик, Махараштра 422006, Индия)

${ }^{3}$ Медицинский колледж Университета Центральной Флориды (Бульвар Лейк-Нона, 6850, Орландо, Флорида 32827, США)

${ }^{4}$ Детская больница Арнольда Палмера (ул. У. Миллера, 92, Орландо, Флорида 32806, США)

Для контактов: Сиби Гопинатх, e-mail: sibygopinath@aims.amrita.edu

\section{PEЗЮME}

Синдром Леннокса-Гасто (СЛГ) - это эпилептическая энцефалопатия, характеризующаяся задержкой умственного развития и трудноизлечимыми приступами нескольких типов, преимущественно тоническими. Приступы падения являются наиболее распространенным и наиболее инвалидизирующим типом припадков. При СЛГ резекционная хирургия часто невозможна, поскольку аномалии электроэнцефалограммы (ЭЭГ) обычно многоочаговые и генерализованные, а магнитно-резонансные томограммы часто бывают нормальными или свидетельствуют о множественных поражениях. Мы приводим клинический случай СЛГ с двусторонним париетозатылочным глиозом. При выполнении ЭЭГ до и после каллозотомии регистрировались синхронизированные двусторонние интериктальные эпилептиформные разряды, а иктальные разряды сократились и десинхронизировались. Указанный френомен подчеркивает роль мозолистого тела во вторичной билатеральной синхронизации.

\section{КЛЮЧЕВЫЕ СЛОВА}

Эпилептическая энцефалопатия, синдром Леннокса-Гасто, мозолистое тело, каллозотомия.

Статья поступила: 08.06.2021 г.; в доработанном виде: 07.07.2021 г.; принята к печати: 12.08.2021 г.

\section{Конфликт интересов}

Авторы заявляют об отсутствии необходимости раскрытия конфликта интересов в отношении данной публикации.

\section{Вклад авторов}

Авторы сделали эквивалентный вклад в подготовку публикации.

\section{Для цитирования}

Гопинатх С., Пиллаи А., Диван А., Паттисапу Дж.В., Радхакришнан К. Подтверждение роли мозолистого тела в генерализации интериктальных и иктальных эпилептиформных разрядов: клинический случай с выполнением интракраниальной электроэнцефалографии после каллозотомии при синдроме Леннокса-Гасто. Эпилепсия и пароксизмальные состояния. 2021; 13 (3): 249-253 (на англ. яз.). https://doi.org/10.17749/2077-8333/epi.par.con.2021.086

\section{INTRODUCTION / ВВЕДЕНИЕ}

Corpus callosotomy was first introduced as a surgical technique for treatment of epilepsy in 1940 [1]. Dr. William $P$ van Wagenen from his observations on patients who underwent surgeries for tumours involving corpus callosum (CC) found that generalized seizures became less frequent when they sectioned CC. This paved the way for evolution of corpus callosotomy into an important epilepsy surgery toolset.

Corpus callosum is a large neural bundle connecting both cerebral hemispheres anatomically and physiologically and is mainly responsible for the rapid generalization of epileptic discharges. Hence callosal sectioning should prevent generalization of seizures [2]. Corpus callosum also has the capacity for simultaneous hemispheric recruitment of seizures. Therefore callosotomy should also reduce the frequency of seizures independent of its role in transhemispheric transmission of epileptic discharges [2].

Corpus callosotomy is proved to be effective for intractable epileptic encephalopathy like Lennox-Gastaut syndrome (LGS) [3]. LGS is a severe epileptic encephalopathy which is characterized by a triad of multiple seizure types, distinct slow spike and wave electroencephalogram (EEG) pattern as well as cognitive impairment. Of the multiple seizure types, the most disabling drop attacks respond better to corpus callosotomy [3]. Although corpus callosotomy is an established palliative surgery in the treatment of medically refractory epilepsy there have been many case reports where callosotomy resulted in uncovering of the single epileptic focus allowing for future resective epilepsy surgery [4]. 
Here we report a case of subject with symptomatic LGS secondary to bilateral parieto-occipital gliosis who underwent callosotomy following an intracranial EEG performed to rule out a dominant unilateral focus. The intracranial EEG was continued into the postoperative period and we demonstrated running down of bilateral synchronous occipital discharges and unmasking of a probable dominant unilateral focus.

\section{CASE REPORT / КЛИНИЧЕСКИЙ СЛУЧАЙ}

A 4-year-old boy suffered from neonatal hypoglycemia and focal seizures on the second day of life, increasing to 1-2 events per week over 2 years despite being on anticonvulsants. He had multiple seizure types including gelastic, right versive seizures, and tonic-drop attacks associated with frequent head injuries. His cognition was subnormal, visual tracking was impaired and vocabulary was limited to two words. The patient had mild right hemiparesis and required assistance for walking. MRI showed volume loss and bilateral parieto-occipital gliosis. A written consent to publish the clinical case was obtained from the patient (minor's father).

During video-scalp EEG monitoring, the interictal EEG showed a slow background activity, with frequent multifocal and posterior dominant generalized interictal epileptiform discharges (IEDs). During sleep, burst suppression pattern was recorded. Twelve habitual events were captured, suggestive of axial tonic and myoclonic tonic seizures with drop attacks (Fig. 1). Ictal EEG showed generalized high amplitude slow waves followed by electrodecremental pattern.

Patient was diagnosed with symptomatic LGS resulting from bilateral parieto-occipital gliosis. In view of mild right hemiparesis as well as multifocal and generalized IEDs with bilateral parieto-occipital gliosis, an intracranial EEG exploration was planned to rule out a dominant unilateral epileptogenic focus (suspecting left side generation). The parents were counselled for a possible unilateral posterior quadrantic disconnection with a better prognosis versus corpus callosotomy, should the invasive recordings prove a dominant unilateral focus. If bilateral independent ictal onset foci were recorded, we planned to proceed with a corpus callosotomy for symptomatic relief from the drop attacks.

Invasive video-EEG monitoring showed very active IEDs over right mesial parieto occipital and left mesial parietal and occipital contacts. Twenty-five electroclinical events were recorded with bilateral seizure onset, and initial ictal discharges (IDs) were seen over the left temporo-occipital inner contacts and right mesial parieto-occipital region contacts synchronously. Because the invasive recording showed bisynchronous ictal onsets, we proceeded with total callosotomy and electrodes were maintained for post-procedural EEG monitoring. Post-callosotomy intracranial EEG showed complete disappearance of bisynchronous IEDs with frequent focal sharp and slow waves only over the innermost contacts in the right mesial occipital region (Fig. 2). We also recorded 16 partial motor seizures involving the left upper limb with EEG onset from the innermost contacts of right mesial occipital region. No IEDs from the left hemisphere were observed. Following a running-down period of 24 hours, the child has remained seizure-free for 6 months, and then developed subtle neck drops twice weekly with significantly improved attention and cognition.

At 66 months follow up, the child is doing well without drop attacks and occasional unilateral jerking of the left arm and face. Anticonvulsant drugs were tapered down to 3 . The patient became less hyperactive and is undergoing speech

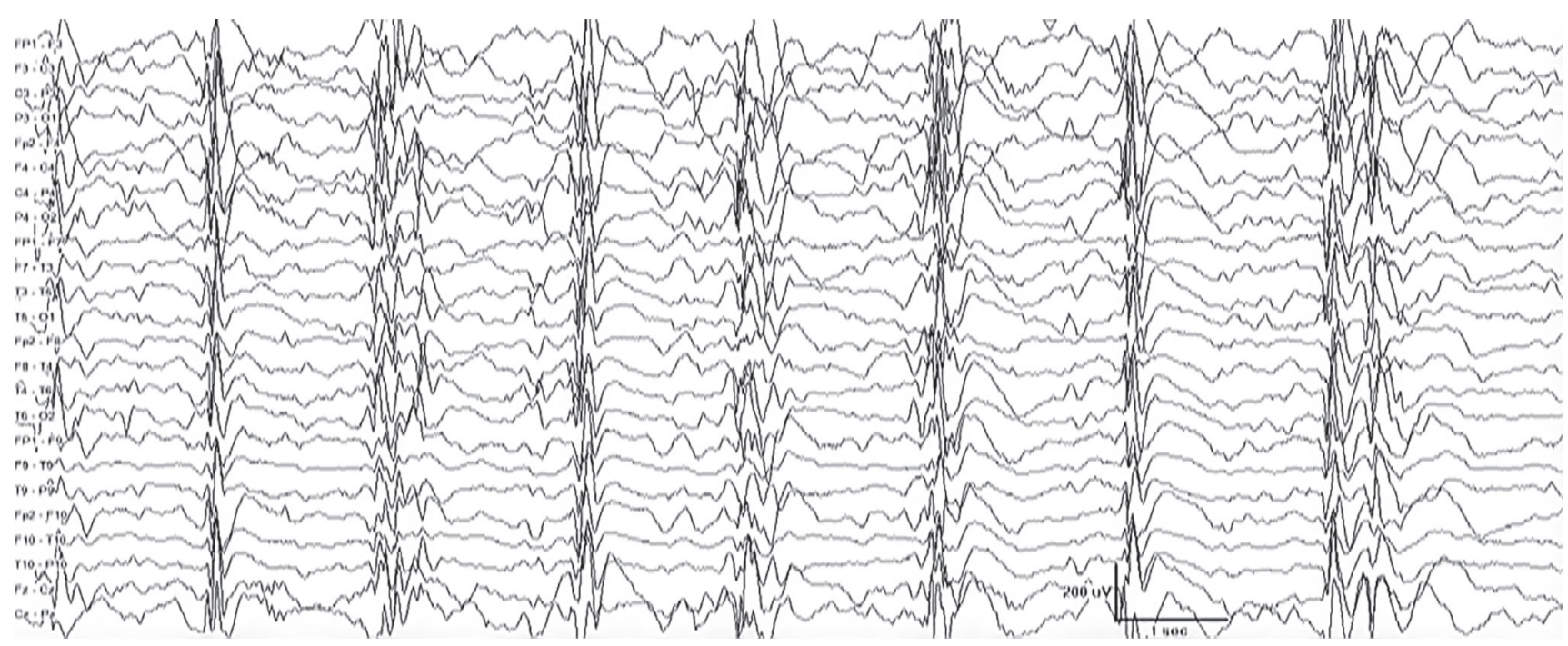

Figure 1. Pre-callosotomy scalp electroencephalogram: bursts of generalized bilaterally synchronous spikes, polyspikes and slow waves

Рисунок 1. Скальповая электроэнцефалография перед каллозотомией: вспышки генерализованных двусторонних синхронных спайков, полиспайков и медленных волн 


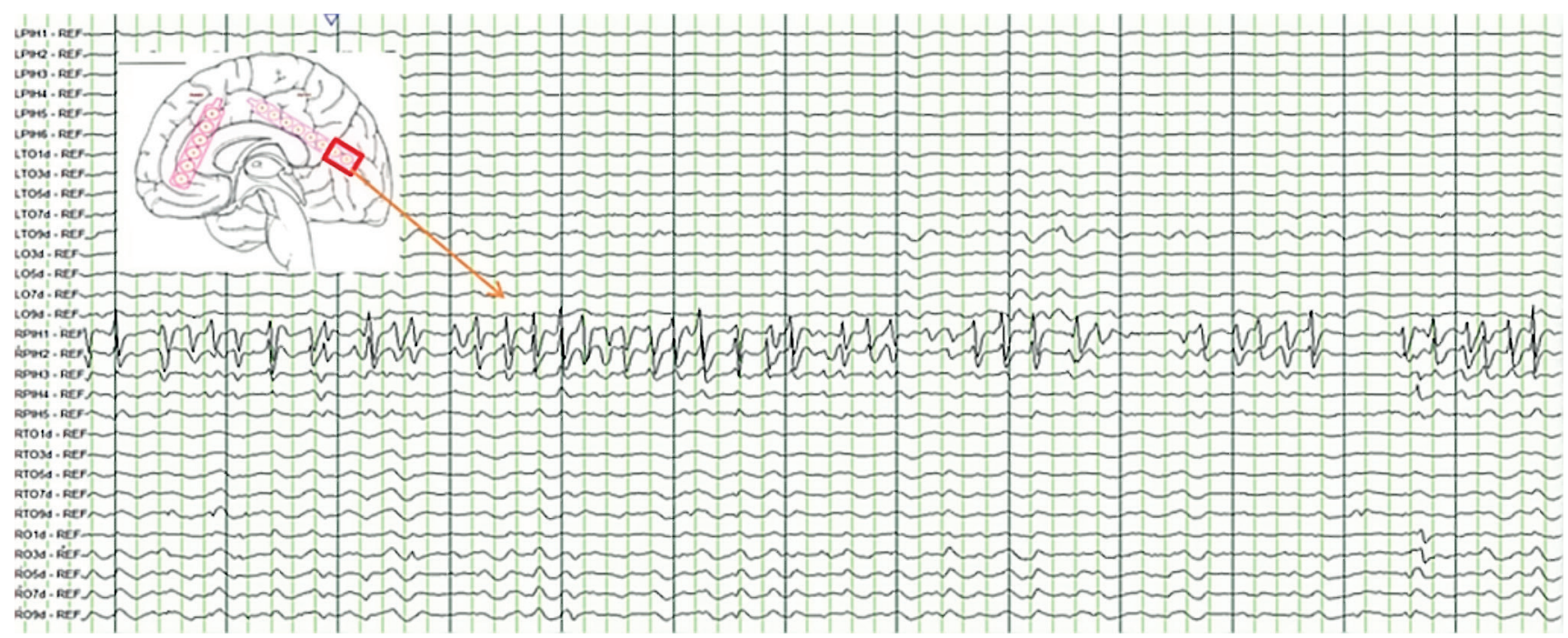

Figure 2. Post-callosotomy intracranial electroencephalogram showed disappearance of generalized spike and waves and focal active discharges from the inner contacts of right mesial occipital region

Рисунок 2. Интракраниальная электроэнцефалография после каллозотомии показала исчезновение генерализованных спайков и волн, а также очаговых активных разрядов с внутренних контактов в мезиальной затылочной области правого полушария

therapy for verbal development. Scalp EEG on follow up showed bilateral independent posterior region spiking.

\section{DISCUSSION / ОБСУЖДЕНИЕ}

Drop attacks are the most disabling feature of LGS and are known to be caused by secondary bilateral synchrony. This rapid spread via the CC explains the efficacy of callosotomy in reducing drop attacks in LGS patients [1, 4-10]. As far as we know, this is the first case of pre-callosotomy intracranial EEG that was continued into the post-callosotomy period and the first intracranial EEG demonstration of rapid desynchronization of bilateral epileptogenic foci in LGS immediately after callosotomy.

Several hypotheses regarding how callosotomy reduces seizure frequency have been proposed. The CC, through its rich connectivity between the hemispheres, enhances bilateral synchronization and generalization of IEDs and IDs [1, 4-10]. Callosotomy disconnects the pathways between homologous areas of two hemispheres, disrupting the synchronized IEDS and IDs and revealing the primary focus (focal discharges) [4-6].

$\mathrm{H}$. Oguni et al. found that callosotomy can distinguish between primary versus secondary bilateral synchrony [5]. The secondary bilateral synchrony (SBS) is feaured with disappearance of IEDs post-callosotomy on the contralateral side, suggesting a primary epileptic focus with secondary bilateral synchrony, similar to our case. In contrast, bilateral independent IEDs persisted in post-callosotomy PBS (primary bilateral synchrony) patients [5]. However, the authors also hypothesized that CC plays both facilitatory and inhibitory roles on interhemispheric spread of seizures [5].This phenomenon accounts for the increased or newly developed IEDs and IDs in the less involved hemisphere due to being released from the inhibitory effect of callosal fibres.

S.S. Spencer et al. also postulated that generalized IEDs may persist post-callosotomy, indicating the presence of extra-callosal diencephalic and brainstem pathways involved in synchronization of IEDs [6]. However post-callosotomy ictal onsets showed absence of bisynchronous IDs, favouring a major role for CC in the interhemispheric transfer of seizure discharges. Post-callosotomy, significant decrease in IEDs could be due to reciprocal facilitation of the cortical epileptic susceptibility by the CC apart from disrupted synchronization. Direct recording of callosal compound action potentials, further supports the evidence that CC is not just a pathway for propagating epileptiform discharges but has the capacity for simultaneous hemispheric recruitment. In the present case, we recorded focal motor seizures immediately post-callosotomy with ictal onset from the right mesial occipital region, which ran down over 24 hours. Similar observation was noted by S.S. Spencer et al., where 5 out of 17 post-callosotomy patients developed more intense focal seizures [11]. Our patient remained seizure-free except for occasional unilateral jerking of the left arm and face during the 66 month follow-up period.

\section{CONCLUSION / ЗАКЛЮЧЕНИЕ}

We report a case of lesional LGS in which post-callosotomy invasive EEG revealed running down of bilateral occipital synchrony and perhaps a more dominant unilateral focus. If seizures recur with concordant unilateral scalp EEG signs, we propose a future second-stage focal resection/disconnection as appropriate. The intracranial EEG 
findings in our patient highlight not only the utility of corpus callosotomy in patients with symptomatic LGS with bihemispheric lesions, but also its possible mechanism of seizure reduction.

Considering the fact that few series of intraoperative deep intracranial EEG recordings before and after corpus callosotomy have been already published, with similar findings. However, to the best of our knowledge, this is the first case of symptomatic LGS where pre-surgical invasive monitoring was continued till post-operative period, revealing running down of bilateral occipital synchrony and unmasking a more dominant unilateral focus. Essential to mention, the current patient described here is the first case of pre-callosotomy intracranial EEG that was continued into the post-callosotomy period, and the first intracranial EEG demonstrated rapid desynchronization of bilateral epileptogenic foci in LGS immediately following callosotomy.

\section{REFERENCES / ЛИТЕРАTУРА:}

1. Mathews M.S., Linskey M.E., Binder D.K. William P. van Wagenen and the first corpus callosotomies for epilepsy. J Neurosurg. 2008; 108 (3): 608-13. https://doi.org/10.3171/JNS/2008/108/3/0608.

2. Matsuo A., Ono T., Baba H., Ono K. Callosal role in generation of epileptiform discharges: quantitative analysis of EEGs recorded in patients undergoing corpus callosotomy. Clin Neurophysiol. 2003; 114 (11): 2165-71. https://doi.org/10.1016/S1388-2457(03)00234-7.

3. Oguni H., Olivier A., Andermann F., Comair J. Anterior callosotomy in the treatment of medically intractable epilepsies: a study of 43 patients with a mean follow-up of 39 months. Ann Neurol. 1991; 30 (3): 357-64. https://doi.org/10.1002/ana.410300307.

4. Hur Y.J., Kang H.C., Kim D.S., et al. Uncovered primary seizure foci in Lennox-Gastaut syndrome after corpus callosotomy. Brain Dev. 2011; 33 (8): 672-7. https://doi.org/10.1016/j.braindev.2010.11.005.

5. Oguni H., Andermann F., Gotman J., Olivier A. Effect of anterior callosotomy on bilaterally synchronous spike and wave and other EEG discharges. Epilepsia. 1994; 35 (3): 505-13. https://doi. org/10.1111/j.1528-1157.1994.tb02469.x.

6. Spencer S.S., Katz A., Ebersole J., et al. Ictal EEG changes with corpus callosum section. Epilepsia. 1993; 34 (3): 568-73. https://doi. org/10.1111/j.1528-1157.1993.tb02597.x.
7. Chen P.C., Castillo E.M., Baumgartner J., et al. Identification of focal epileptogenic networks in generalized epilepsy using brain functional connectivity analysis of bilateral intracranial EEG signals. Brain Topogr. 2016; 29 (5): 728-37. https://doi.org/10.1007/ s10548-016-0493-3.

8. Lin J.H., Kwan S.Y. Post-section recruitment of epileptiform discharges in electrocorticography during callosotomy in 48 patients with Lennox-Gastaut syndrome. J Clin Neurosci. 2012; 19 (3): 388-93. https://doi.org/10.1016/j.jocn.2011.04.044.

9. Salayev K.A., Nakasato N., Ishitobi M., et al. Evaluation of interhemispheric time difference by magnetoencephalography before and after total callosotomy. Two case reports. Neurol Med Chir (Tokyo). 2006; 46 (3): 136-42. https://doi.org/10.2176/nmc.46.136.

10. Kwan S.Y., Lin J.H., Wong T.T., et al. Prognostic value of electrocorticography findings during callosotomy in children with Lennox-Gastaut syndrome. Seizure. 2005; 14 (7): 470-5. https://doi. org/10.1016/j.seizure.2005.07.011.

11. Spencer S.S., Spencer D.D., Glaser G.H., et al. More intense focal seizure types after callosal section: the role of inhibition. Ann Neurol. 1984; 16 (6): 686-93. https://doi.org/10.1002/ ana.410160611.

\section{About the authors}

Siby Gopinath - MD, Clinical Professor, Department of Neurology, Amrita Advanced Centre for Epilepsy, Amrita Institute of Medical Science (Kochi, Kerala, India). ORCID ID: https://orcid.org/0000-0002-3333-0933. E-mail: sibygopinath@aims.amrita.edu.

Ashok Pillai - MD, Professor, Department of Neurosurgery, Amrita Advanced Centre for Epilepsy, Amrita Institute of Medical Science (Kochi, Kerala, India).

Anand G. Diwan - MD, Consultant Neurologist, Narayani Hospital (Nashik, Maharashtra, India).

Jogi V. Pattisapu - MD, Emeritus Medical Director, Pediatric Neurosciences, University of Central Florida College of Medicine; Arnold Palmer Hospital for Children (Orlando, Florida, USA).

Kurupath Radhakrishnan - MD, Professor, Amrita Advanced Centre for Epilepsy, Amrita Institute of Medical Science (Kochi, Kerala, India).

\section{Сведения об авторах}

Сиби Гопинатх - доктор медицины, клинический профессор, отделение неврологии Передового центра эпилепсии «Амрита» Института медицинских наук «Амрита» (Кочин, штат Керала, Индия). ORCID ID: https://orcid.org/0000-0002-3333-0933. E-mail: sibygopinath@aims.amrita.edu.

Ашок Пиллаи - доктор медицины, профессор, отделение нейрохирургии Передового центра эпилепсии «Амрита» Института медицинских наук «Амрита» (Кочин, штат Керала, Индия).

Ананд Г. Диван - доктор медицины, консультант-невролог, Больница «Нараяни» (Нашик, штат Махараштра, Индия).

Джоги В. Паттисапу - доктор медицины, почетный директор по медицине отделения педиатрической неврологии Медицинского колледжа Университета Центральной Флориды; Детская больница Арнольда Палмера (Орландо, штат Флорида, США).

Курупат Радхакришнан - доктор медицины, профессор, Передовой центр эпилепсии «Амрита» Института медицинских наук «Амрита» (Кочин, штат Керала, Индия). 